\title{
Determinants of Young Sri Lankan Individuals' Intention to Engage in Viral Marketing
}

\author{
Irosha Perera and Pradeep Dharmadasa
}

\begin{abstract}
Despite the prolific growth of viral marketing, factors that determine successful viral marketing campaigns remain largely unknown. Since the extant literature postulates that individual who pass along messages play a vital role in viral marketing, this paper examines the factors that determine the individuals' message pass along intention in light of the behavioural theory proposed by Ajzen, namely, the Theory of Planned Behavior (TPB), and the interpersonal relations theory proposed by Schutz, namely, Fundamental Interpersonal Relations Orientation (FIRO). The data collected from 391 young undergraduates in Sri Lanka were analyzed using the Structural Equation Modeling method. The results revealed that perceived behavioural control, attitude towards viral marketing, subjective norms, and need for affection and need for control are influential in determining the intention among young individuals to engage in viral marketing. Thus, the findings reveal that firms may need to develop different strategies to manipulate those critical factors that affect one's intention to engage in viral marketing so as to enhance the effectiveness of viral marketing campaigns.
\end{abstract}

Keywords: electronic word of mouth (eWOM), Fundamental Interpersonal Relations Orientation (FIRO), intention, Theory of Planned Behaviour (TPB), viral marketing.

\section{Introduction}

The proliferation of information and communication technology (ICT) opened many opportunities as well as challenges for businesses around the globe. Marketing

Irosha Perera is a Lecturer of School of Business, National School of Business Management. E-mail : irosha@nsbm.lk (Corresponding author).

Pradeep Dharmadasa, $\boldsymbol{P h D}$ is a Senior Lecturer and presently Head of the Department of International Business, Faculty of Management and Finance, University of Colombo. 
communication has expanded widely with the support of ICT, whereby it is no longer restricted to the conventional one-way firm-to-consumer or to the more recent two-way or bidirectional communication. Communication flows in diverse directions, exploring the links or relations that individuals have with others through information and communication technology (Camarero \& San Jose 2011). Since customers face great exposure to the world it is imperative that organizations work on tapping them by using every possible method by which they gather exposure. Among the many new marketing communication tools that have evolved, viral marketing has become a very important tool (De Bruyn \& Lilien as cited in José-Cabezudo \& Camarero-Izquierdo 2013) because of its inherent characteristics that strongly support marketing innovations.

Viral marketing can be defined as electronic word of mouth whereby some form of marketing message related to a company, brand or product is transmitted in an exponentially growing way, often through the use of social media applications (Kaplan \& Haenlein 2011). The terms "viral marketing" and "eWOM" are often used interchangeably (Camarero \& San Jose 2011; Ho \& Dempsey 2010; Vilpponen, Winter \& Sundqvist 2006) and this study also uses does likewise. Previous studies have shown that eWOM is more influential than traditional marketer-created information because it is perceived to be more impactful, convenient and credible (Cheung \& Thadani 2012, Henning-Thurau, Gwinner, Walsh \& Gremler 2004, Bickart \& Schindler 2001). Moreover, industry research reports have also substantiated the fact that when making purchase decisions, internet users trust online reviews posted by unknown consumers more than they trust the traditional media (eMarketer, Inc 2013).

Despite the propagation of eWOM over the years, it is only very recently that eWOM received serious managerial and academic attention (Cheung \& Lee 2012). The extensive studies done on viral marketing have been mainly about the effectiveness of eWOM communication where the focus was on purchase intention, purchasing decision and repurchase intention (Cheung \& Thadani 2012; Chan \& Ngai 2011) with only limited academic attention given to the critical factors affecting successful viral marketing campaigns (Cheung \& Lee 2012, Chan \& Ngai 2011, Henning-Thurau, Gwinner, Walsh \& Gremler 2004). According to Chan and Ngai (2011), among the studies conducted with regard to eWOM, only $20 \%$ focused on the factors critical to efficacious viral marketing campaigns. They point out that the success of eWOM campaigns is largely determined by two factors, namely, the message and the sender. Moreover, even with the rapid growth of Social Networking Sites (SNS), much of viral marketing research has been more focused on website interactions (Chan \& Ngai 2011) and less on the intention to engage in viral marketing through SNS. 
Further, most of the research on eWOM has been done in developed countries in the western world but little in the Asian context and that also confined to developed countries like Korea and Hong Kong (Chan \& Ngai 2011). Therefore, the findings of such research may not be applicable to developing countries because of the socio-cultural and economic differences between developed and developing nations. In viral marketing in Sri Lanka, many of the Sri Lankan brands have still not begun to reap the maximum benefits of using eWoM through SNS (Thajudeen 2012). An exception to this has been recorded in the Sri Lankan political arena where eWOM was used effectively as a promotional tool. According to Abbas \& Singh (2014), Prime Ministerial candidate Narendra Modi realized the potential of social media and used it as a key tool in his campaign. In the Sri Lankan political arena there was an unprecedented use of the social media by both presidential candidates as well as by the politically charged but yet unaffiliated youth (Gunawardena 2015). With this in mind, this paper aims to investigate the factors affecting Sri Lankan youths' intention to engage in viral marketing, particularly in political events via social networking sites (SNS).

The remainder of the paper is organized as follows: section two presents the theoretical background of the study; section three outlines the research method; section four presents the results and findings of the study; and section five provides the discussion and conclusions of the study followed by research implications, limitations and directions for future research.

\section{Theoretical Background}

Scholars widely perceive online content forwarding as a unique behaviour (Lee, Ham \& Kim 2013, Camarero \& San Jose 2011, Yang 2013, Yang, Liu \& Zhou 2012, Hsu \& Lin 2008) and behavioural intention as a more influential predictor of behaviour (Pavlou \& Fygenson 2006). Intentions are presumed to capture the motivational factors which influence behaviour and they are indications of how hard people are willing to try or how much of an effort they plan to exert to perform a particular behaviour (Ajzen 1991). In this regard, the Theory of Planned Behaviour (TPB), an extension of the Theory of Reasoned Action (TRA), provides a useful framework for dealing with the complexities of human social behaviour (Ajzen 1991, Ajzen \& Madden 1986).

TPB is considered to be a well-accepted model that has been used to predict behaviours ranging from classroom participation to dishonest behaviours such as cheating in tests, shoplifting, lying and avoiding assignments. It permitted more accurate predictions of intentions (Ajzen \& Madden 1986). According to TPB, the individual's intention to engage in a particular behaviour depends on his attitude to such behaviour -the degree to which 
a person makes a favourable or unfavourable evaluation or appraisal of the behaviour in question, subjective norms - perceived social pressure to perform or not to perform the behaviour and perceived behavioral control (PBC) -the perceived ease or difficulty of performing the behaviour (Ajzen 1991, Ajzen \& Madden 1986). PBC is a construct which differentiates TPB from TRA where PBC was incorporated owing to the limitations of the original TRA model in dealing with behaviour over which people have incomplete volitional control (Ajzen 1991).

Since intention is presumed to capture the motivational factors which influence behavior, in a study of viral marketing it is pivotal to look at interpersonal communication motives which drive individuals to engage in viral marketing. Related to this, the theory of Fundamental Interpersonal Relations Orientation (FIRO) (Schutz 1966) emphasizes that people engage in interpersonal relations as they are motivated to express one or more of three interpersonal needs, namely, inclusion, affection and control. As engaging in viral marketing is a form of maintaining interpersonal relations, motives that drive the indiviual's intention to engage in viral marketing can be explained in light of the FIRO theory (Schutz 1966). According to FIRO, the need for inclusion refers to the individual's desire to be a part of a group; need for affection refers to an individual's desire to love or to be loved by others; and need for control refers to the need to exert power over others or give power over the self to others. When analyzing the need for inclusion in depth it is seen that while belonging to a group, the individual desires to be identifiable or different from other people (Schutz 1966). This has led to claiming that the need for inclusion is an integration of need to belong and need to be different or individuation. While an individual wants to be a part of a group, he wants to obtain recognition or unique identification among the group members. It has been hypothesized that the individual's intention to engage in viral marketing depends on three factors proposed by Ajzen (1991) and four factors proposed by Schutz (1966), as explained below.

\section{Attitude}

Much of the prior studies related to techonology adpotion and knowledge sharing supported the individual's intention to engage in a particular behaviour being positively related to his/ her attitudes (Mishra, Akman \& Mishra 2014, Taylor \& Todd 1995, Pavlou \& Fygenson 2006, Bock, Zmud, Kim \& Lee 2005, Ranasinghe \& Dharmadasa 2013). This has been further substantiated in the context of viral marketing, where Lee, Ham and Kim (2013) came up with the finding that attitudes positively affect an inidvidual's intention to pass along online video advertisements. Further, in an effort to determine mobile viral marketing behaviour among young Chinese customers, it was revealed that intention to forward useful electronic 


\section{NSBM Journal of Management}

Vol. 2, No. 1, January - June, 2016

messages and entertaining messages was determined by the attitudes to viral messages of senders (Yang, Liu \& Zhou 2012). Yang (2013) asserted that young Chinese consumers' frequency of product recommendations on social networking websites is influenced by their viral marketing attitudes. Based on the above, it can be assumed that the more favourable the attitude towards a particular behaviour, the stronger the intention to engage in it. Thus, we hypothesise that

$\mathrm{H}_{1}$ : Attitude towards viral marketing positively influences intention to engage in viral marketing of political events through SNS.

\section{Subjective Norms}

Subjective norms reflect consumer perceptions of whether particular behaviours are accepted, encouraged and adopted by the consumer's circle of influence (Pavlou \& Fygenson 2006, Hsu \& Lin 2008, Palka, Pousttchi \& Wiedemann 2009). The impact of subjective norms on the intention to engage in a given behaviour has been studied along diverse lines of research, the findings of which reveal positive relationships. Substantiating the findings of TPB (Ajzen 1991), empirical studies have shown that subjective norms influence intention to adopt technology (Taylor \& Todd 1995, Pavlou \& Fygenson 2006, Hsu \& Lu 2004 and Mishra, Akman \& Mishra 2014). Moreover, prior research underlines that subjective norms of knowledge-sharing positively affect the intention to share knowledge (Bock , Zmud , Kim \& Lee 2005, Ranasinghe \& Dharmadasa 2013). In addition, a significant positive impact of subjective norms on intention to engage in viral marketing has been shown in different contexts (Yang 2013, Yang, Liu \& Zhou 2012, Lee, Ham \& Kim 2013). Since the extant literature supports the thesis that subjective norms positively impact on intention to engage in behavior, the following hypothesis is proposed:

$\mathrm{H}_{2}$ : Subjective norms in respect of viral marketing positively influence intention to engage in viral marketing of political events through SNS.

\section{Perceived Behavioural Control}

Perceived behavioural control (PBC) is the person's belief as to how easy or difficult his/ her behaviour is likely to determine his/her intention (Ajzen 1991). An individual's intention to engage in a particular behaviour will be shaped by how he/she percieves his/her ability to perform. The positive impact of PBC on the individual's intention has been recognized in 
the existing literature on technology adoption (Han, Hsu \& Sheu 2010, Taylor \& Todd 1995, Grunert \& Ramus 2005, Askew, et al., 2014, Ross, et al., 2009, Cheung \& Vogel 2013). In regard to knowledge-sharing behaviour, Lin and Lee (2004) found that percieved ease of sharing knowledge with others positively impacts on the individual's intention to engage in knowledge-sharing. Since PBC is shown to generate a significant positive effect on intention to engage in techonology adoption as well as in knowledge-sharing, this study hypothesises that:

$\mathrm{H}_{3}$ : $\quad$ PBC positively influences intention to engage in viral marketing of political events through SNS.

\section{Need to Belong}

Every individual has a strong desire to be a part of a particular community and to maintain interpersonal relationships. Schutz (1966) recognizes that the need to belong involves including significant others in a circle of acquaintances and remaining "in the loop". By nature, people are in need of love and social acceptance, which is referred to as the "need to belong" (Leary, Kelly, Cottrell \& Schreindorfer 2013). In their study exploring the determinants of word of mouth in online consumer platforms, it was found that the feeling of being emotionally involved with the group had a significant impact on consumers' eWOM intentions (Cheung \& Lee 2012). Further, Phelps, Lewis, Mobilio, Perry and Raman (2004) asserted that consumers' motivations to pass along emails are backed by the desire to connect and share with others. Thus, the need to belong could be considered to have a positive influence on the intention to engage in viral marketing of political events in Sri Lanka. Thus, it is hypothesized that

$\mathrm{H}_{4}$ : The need to belong positively influences intention to engage in viral marketing of political events through SNS.

\section{Need for Individuation}

While belonging to a particular group, individuals seek to stand out in their group and to make themselves different from others. It has been accepted that social behaviour often occurs with reference to other people and is also evaluated in those terms. Some behavioural options are chosen for the purpose of creating a particular social image whereas others are selected for the function of self-expression (Maslach, Stapp \& Santee 1985). Anything that enhances 


\section{NSBM Journal of Management}

Vol. 2, No. 1, January - June, 2016

an individual's self-image, self-expression and self-determination drives the individual to engage in that behaviour. For example, if an individual perceives that spreading eWOM will enhance his/her self- image, he/she will engage in eWOM. In an effort to reveal the underlying motives for consumers engaging in WoM communication, it has been revealed that the need for self-enhancement is a key motivator that drives individuals to engage in positive WOM (Sundaram, Mitra \& Webster 1998, Henning-Thurau, Gwinner, Walsh \& Gremler 2004). Individuals expect to show their expertise, to enhance their status and seek appreciation for their enhanced self-image through passing along messages. Chung and Darke (2006) found that individuals were more likely to engage in WOM for products that tell others about who you are and which make you unique and which are closely aligned to one's self-image. In their work, Ho and Dempsey (2010) found that individuation or the need to stand out in a crowd was a key motive for an individual to engage in eWOM. Thus, the need for individuation could be considered to have a positive influence on the intention to engage in viral marketing related to political events. Thus, it is hypothesized that:

$\mathrm{H}_{5}$ : The need for individuation positively influences intention to engage in viral marketing of political events through SNS.

\section{Need for Affection}

Love and care are among the foremost needs of an individual. Affection has been defined as the need to establish and maintain a relationship of mutual warmth, care and love with others (Schutz 1966). Individuals desire to express and receive love and care in any relationship they maintain in a physical or virtual context. To have such mutual warmth, the individual should be willing to help others in a selfless manner. The act of doing something for others without anticipating any reward in return is altruism (Sundaram, Mitra \& Webster 1998). Many scholars have identified that altruism, willingness to help others whole heartedly without expecting anything in return, has a positive effect on eWOM intention (Henning-Thurau, Gwinner, Walsh \& Gremler 2004 and Hsu \& Lin 2008)). Further, that affection positively affects eWOM intentions has been substantiated by Ho \& Dempsey (2010), Phelps, Lewis, Mobilio, Perry \& Raman, (2004), Huang, Lin, \& Lin 2008 and Cheung \& Lee (2012). It is presumed that during an election period politically uncharged individuals spread online content to enlighten others without expecting any benefit in return. Thus, it is hypothesized that:

$\mathrm{H}_{6}$ : The need for affection positively influences intention to engage in viral marketing of political events through SNS. 


\section{Need for Control}

The need for control is the desire to exert power over others or to give power over one's self to others (Rubin, Perse \& Barbato 1988). Schutz (1966) emphasized that the need for control is an imperative motivation for individual interpersonal relationships including interpersonal communication. Substantiating the finding that the need for control is an interpersonal need (Schutz 1966), the Interpersonal Communication Motives (ICM) scale developed by Rubin, Perse, \& Barbato (1988) has also identified the need for control as a motive for individuals to engage in interpersonal communication. Smith (2012) suggested that achieving superiority and influencing power is a main motivation for passing eWOM communication in websites and blogs. In addition, Sun, Youn, $\mathrm{Wu}$, and Kuntaraporn (2006) found that online opinion leadership is positively related to online forwarding in the context of music-related communication. Opinion leaders are presumed to be influential members of their social network with a desire to control others (Chaney 2001). Hence, the need for control could be considered to have a positive impact on the intention to engage in viral marketing relating to political events in Sri Lanka. Thus, it is hypothesized that:

$\mathrm{H}_{7}$ : The need for control positively influences intention to engage in viral marketing of political events through SNS.

The conceptual framework of the study based on the above discussion is given in Figure 1.

\section{Figure 1: Conceptual Framework}

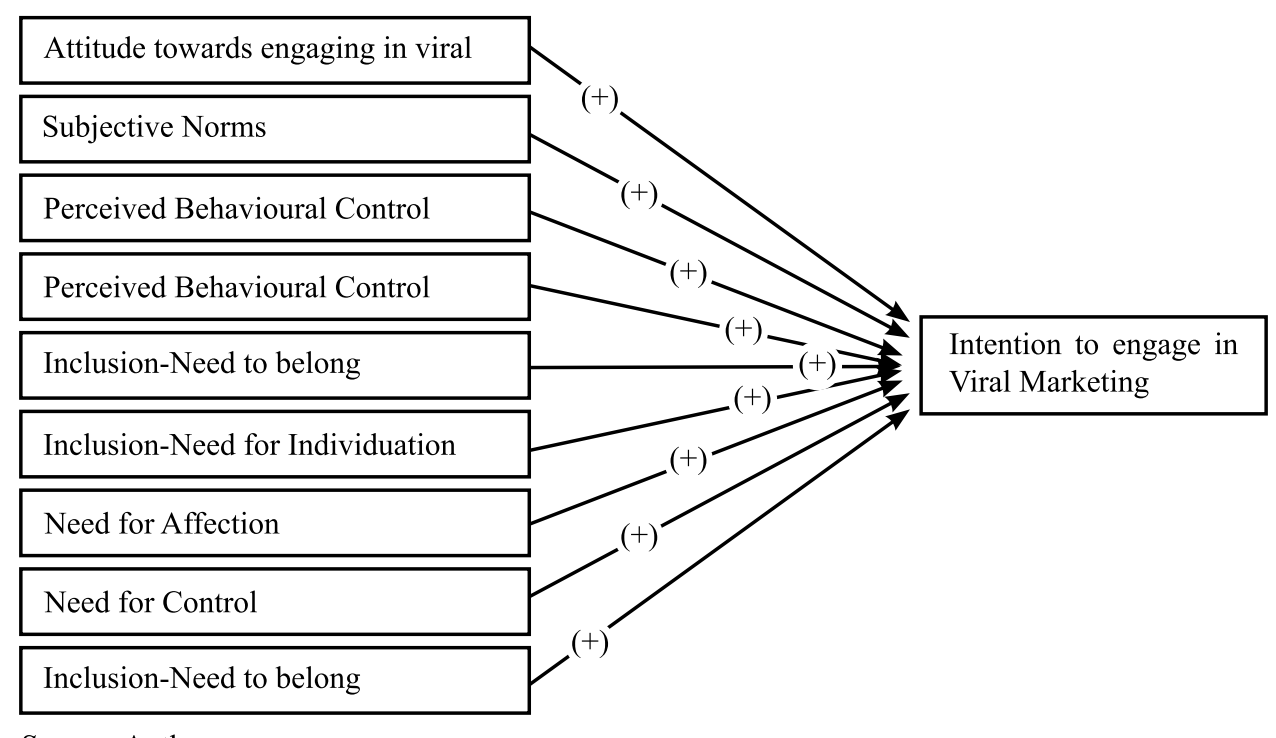

Source: Author 
NSBM Journal of Management

Vol. 2, No. 1, January - June, 2016

\section{Research Method}

\section{Data Collection and Sample}

Data for the study was collected from 400 undergraduates registered for different degree programmes at four higher educational institutions in Colombo district, aged between 18 and 24 and active in at least one social media network. Convenience sampling was used and data collected through a questionnaire. Much of the previous research has proposed that young adults are the most appropriate segment for conducting studies on viral marketing as they form the demographic group with the highest rates of technology adaptation and viral marketing penetration (Lee, Ham \& Kim 2013, Camarero \& San Jose 2011, Ho \& Dempsey 2010). The age group 18-24 years was considered because, according to the UN, youth is defined as those persons between the ages of 15 and 24 years (UNESCO 2014) and to qualify as a voter, an individual must have attained the age of 18 years by the date of the relevant register -June 1st. In order to increase the response rate, anonymity was assured and as an incentive a summary of the research findings was offered to the participants. Further, several follow-up procedures were used such as reminder notices to the participants and reminder messages to SNS accounts.

The questionnaire used in this study consisted of three sections: screening questions to ensure respondents were within the age group and have an SNS account; predictor constructs and intention measures; demographic information. To measure the constructs, already established measurement scales were adapted to the Sri Lankan setting. Altogether, there were forty two (42) questions, all of the Likert style rating scales which enable respondents to indicate how strongly they agree or disagree with the statements (Saunders, Lewis \& Thornhill 2011). A five-point Likert scale was used from $1=$ strongly disagree and $5=$ strongly agree (Refer Appendix 01).

\section{Method of Analysis}

Prior to hypotheses testing, the data was examined, and with the support of SPSS, outliers were identified, missing values were treated and multivariate assumptions for the data set tested. The hypotheses of the study were then tested using Structural Equation Modelling (SEM) through AMOS. Following Anderson and Gerbing's (1988) two-step approach, SEM was conducted to analyze the data. The measurement model was first constructed and tested with confirmatory factor analysis (CFA). Secondly, the structural model was specified in order to examine the causal relationships among variables or predictors and criteria. 


\section{Results and Findings}

With the support of SPSS, the data was purified and multivariate assumptions tested. It has been proven that all multivariate assumptions been met. In addition before proceeding into inferential statistics researcher assessed the unidimensionality, validity and the reliability of data. validity and the reliability of the data. Hence, the study was conducted with scaled items and Cronbach's Alpha was used to measure internal consistency (i.e., reliability). Hair, Black, Babin, \& Anderson (2009) recommended that Cronbach's alpha values ranging from 0.6 to 0.7 can be treated as the lower limit of acceptability. Accordingly, Cronbach's alpha for each item was calculated and several items had to be removed from the scales in order to exceed the cut off value of Cronbach's alpha. The NTB construct was identified as a significantly poor variable in terms of internal consistency as the alpha value was 0.484 . With the removal of two items, namely, NTB3_R and NTB7_R, the Cronbach's alpha value was indicated as 0.642 after the purification. All the other variables were considered to be internally consistent as the corresponding alpha values were greater than 0.7 .

The measurement model fit was evaluated through the goodness of fit indices using the absolute, parsimony and incremental measures. Absolute fit indices provide the most fundamental indication of how well the proposed theory fits the data collected in the specific context. Incremental fit indices are a group of indices that do not use the chi-square in its raw form but compare the chi-square value with a baseline model. Parsimony determines which model among a set of competing models is best suited (Hooper, Couglan \& Mullen 2008). According to the values of the goodness of fit indices, a mediocre model fit was established $(\chi 2=1497.618, \mathrm{df}=712, \mathrm{p}<0.001, \mathrm{CIMIN} / \mathrm{DF}=2.103, \mathrm{GFI}=.830, \mathrm{RMSEA}=$ $.055, \mathrm{IFI}=.873, \mathrm{CFI}=.871, \mathrm{PRATIO}=.913)$. Eliminating non-significant items and items with factor loadings below 0.5 was considered to improve the model fit (Hair, Black, Babin $\&$ Anderson 2009). In addition, as suggested by Hair et al. (2009), modification indices were used to improve the model. The modified measurement model's fit was evaluated with the goodness of fit indices and the results showed a satisfactory fit to the data $(\chi 2=892.159$, df $=523, \mathrm{p}<0.001, \mathrm{CIMIN} / \mathrm{DF}=1.706, \mathrm{GFI}=.884, \mathrm{RMSEA}=.044, \mathrm{IFI}=.936, \mathrm{CFI}=.935$, PRATIO $=.879)$. All items loaded above 0.50 and were significantly associated with their specified constructs $(\mathrm{p}<0.001)$. These results provided evidence for the unidimensionality of each scale.

Convergent validity measures the extent to which a scale has a positive correlation with other measures of the same latent construct (Sekaran \& Bougie 2014). Assessing factor loadings is a commonly used method to determine convergent validity where higher factor loadings 


\section{NSBM Journal of Management}

Vol. 2, No. 1, January - June, 2016

represent higher convergent validity while all factor loadings should be statistically significant. Hair, Black, Babin, \& Anderson (2009) determined that the threshold value for higher factor loading is the standardized loading estimates which should be 0.5 or higher, and ideally 0.7 . The Average Variance Extracted (AVE) which calculates the mean variance extracted for the items loading on a construct is another indicator of convergence. It is accepted that AVE of .5 or higher is a good rule of thumb to ensure adequate convergence (Bagozzi \& Yi 1988). Further, Construct Reliability (CR) was also introduced as an indicator of convergent validity and the values greater than.6 were desirable for CR (Bagozzi \& Yi 1988).

Discriminant validity emphasizes the extent to which a construct is truly distinct from other constructs in a model (Hair, Black, Babin \& Anderson 2009). This indicates that the measured variables have more in common with the construct they are associated with than they do with the other constructs. A more rigorous way to determine discriminant validity can be the comparison of the square root of the AVE and the correlation coefficients. If the square root of AVE is larger than the correlation coefficients, discriminant validity is established (Malhotra \& Dash 2011).

Accordingly, a measurement model was used to assess convergent and discriminant validity. Table 1 shows AVE, CR, Correlations, Square Roots of AVE values for each variable.

Table 1: CR, AVE, Correlation Coefficients

\begin{tabular}{lcccccccccc}
\hline & CR & AVE & ATT & NTI & NTB & NFA & SN & NFC & PBC & INT \\
\hline ATT & 0.799 & 0.578 & 0.760 & & & & & & & \\
NTI & 0.829 & 0.352 & 0.203 & 0.593 & & & & & & \\
NTB & 0.742 & 0.326 & 0.007 & 0.064 & 0.571 & & & & & \\
NFA & 0.932 & 0.732 & 0.734 & 0.086 & -0.045 & 0.856 & & & & \\
SN & 0.867 & 0.697 & 0.064 & 0.158 & 0.134 & 0.077 & 0.835 & & & \\
NFC & 0.826 & 0.614 & 0.588 & 0.061 & -0.014 & 0.636 & 0.123 & 0.784 & & \\
PBC & 0.747 & 0.498 & 0.115 & 0.273 & 0.064 & 0.171 & 0.465 & 0.216 & 0.705 & \\
INT & 0.789 & 0.558 & 0.302 & 0.174 & 0.074 & 0.307 & 0.411 & 0.366 & 0.770 & 0.747 \\
\hline
\end{tabular}

Source: Author compiled based on Survey Data

In respect of the measures, all factor loadings were statistically significant and the standardized loading estimates met the minimum threshold of 0.5 , which provided a reasonable estimation of convergent validity among item measures. Table 1 shows that following Bagozzi and Yi's (1988) proposition, the CR of the constructs was confirmed with all constructs demonstrating 
a value which exceeds 0.6 , which is another indicator of convergent validity. However, AVE for all constructs exceeded the threshold of 0.5 except for the constructs NTB and NTI. According to Malhotra and Dash (2011), AVE is considered to be a more conservative measure than $\mathrm{CR}$. Thus, on the basis of $\mathrm{CR}$ alone, the researcher has the discretion to conclude that the convergent validity of the construct is adequate. Therefore despite the low AVE values for constructs NTB and NTI, convergent validity was confirmed with sufficient backing from factor loadings and CR. Discriminant validity for all the constructs except PBC and INT was established with the square root of AVEs being larger than the corresponding correlation coefficients.

\section{Structural Model}

The causal relationships among the latent constructs in the model and hypotheses were tested using the structural model. Before examining the structural model, the model fit was determined. The proposed model displayed an adequate fit to the data $(\chi 2=1577.899$, $\mathrm{df}$ $=548, \mathrm{p}<0.001, \mathrm{CIMIN} / \mathrm{DF}=2.879, \mathrm{GFI}=.829, \mathrm{RMSEA}=.072, \mathrm{IFI}=.829, \mathrm{CFI}=.819$, PRATIO $=.921)$. The statistical results given in Table 2 indicate the path coefficients and level of significance for each construct.

Table 2. Summary of SEM Results

\begin{tabular}{lcc}
\hline Construct & Path Coefficient $(\boldsymbol{\beta})$ & Significance \\
\hline ATT $\rightarrow$ INT & $.191^{*}$ & Significant \\
SN $\rightarrow$ INT & $.220^{* *}$ & Significant \\
PBC $\rightarrow$ INT & $.924^{* *}$ & Significant \\
$\mathrm{ATT} \rightarrow \mathrm{INT}$ & $.191^{*}$ & Significant \\
$\mathrm{SN} \rightarrow \mathrm{INT}$ & $.220^{* *}$ & Significant \\
$\mathrm{NTB} \rightarrow \mathrm{INT}$ & .035 & Not Significant \\
$\mathrm{NTI} \rightarrow \mathrm{INT}$ & -.024 & Not Significant \\
$\mathrm{NFA} \rightarrow \mathrm{INT}$ & $.132^{*}$ & Significant \\
$\mathrm{NFC} \rightarrow \mathrm{INT}$ & $.204^{*}$ & Significant \\
\hline
\end{tabular}

Source: Compiled by authors based on survey data

The statistical results given in Table 3 show that out of the seven hypotheses proposed, five were supported while two were unsupported. Among the interpersonal communication motives, only two hypotheses were supported, suggesting that the need for belongingness 
NSBM Journal of Management

Vol. 2, No. 1, January - June, 2016

and need for individuation may not be possible motives of a young individual's intention to engage in viral marketing of political events through SNS.

Table 3: Results of Hypotheses Testing

\begin{tabular}{ll}
\hline Hypothesis & Results \\
\hline H1: Attitudes toward viral marketing positively influence intention to engage in & Supported \\
viral marketing of political events through SNS. & \\
H2: Subjective norms toward viral marketing positively influence intention to & Supported \\
engage in viral marketing of political events through SNS. & \\
H3: PBC positively influences intention to engage in viral marketing of political & Supported \\
events through SNS. & \\
H4: The need to belong positively influences intention to engage in viral marketing & Not Supported \\
of political events through SNS. & \\
H5: The need for individuation positively influences intention to engage in viral & Not Supported \\
marketing of political events through SNS. & \\
H6: The need for affection positively influences intention to engage in viral & Supported \\
marketing of political events through SNS. & \\
H7: The need for control positively influences intention to engage in viral & Supported \\
marketing of political events through SNS. & \\
\hline
\end{tabular}

\section{Discussion}

The findings of the study confirmed that perceived behavioural control is the most pivotal motivation that governs a young individual's intention to engage in viral marketing of political events in Sri Lanka. This finding was consistent with several prior researches related to the use of information technology and studies related to antecedents of specific behaviors (Han, Hsu \& Sheu 2010, Taylor \& Todd 1995, Grunert \& Ramus 2005, Askew, et al., 2014, Ross, et al., 2009, Lin \& Lee 2004).

However, it was interesting to note that the path coefficient $(\beta)$ established in the study was relatively high compared to the findings of the aforementioned studies. The difference in the degree of the relationship could be mainly due to the differences in the context of the research. In this study, the concern was with intention to engage in viral marketing specifically of political events. This is different from the use of internet for buying purposes or the use of computer resource centres. Unlike other generations' youth are investigative, freely expressive, and the need to authenticate (Smith 2011) thus they perceive lesser obstacles from the political system to express their independent political viewpoints. Further, nowadays young individuals with a wired life style may be technologically capable of navigating and 
expressing themselves in SNS very effectively. Thus, young individuals believe they possess more resources and opportunities and face fewer obstacles or obstructions, resulting in greater perceived behavioural control (Ajzen 1991), which, in turn, form their intentions resulting in a high path coefficient.

With a positive and significant standardized beta coefficient the study confirms that subjective norms have a positive impact on intention to engage in viral marketing related to political events in Sri Lanka. This finding is also in line with many of the previous research findings related to viral marketing and technology adaptation intention (Yang, Liu \& Zhou 2012, Lee, Ham \& Kim 2013, Yang 2013, Taylor \& Todd 1995, Mishra, Akman \& Mishra 2014, Hsu \& Lin 2008). The study established a path coefficient $(\beta)$ of 0.22 , which is much similar to the relationship established in the studies of Yang, Liu \& Zhou (2012) and Taylor \& Todd (1995). Thus, it signifies that when young individuals feel that their friends and relatives accept and engage in viral marketing of political events, they are more likely to spread eWOM or pass along electronic messages about political events in the social media.

The findings of the study indicate that young persons' attitudes have a positive impact on their intention to engage in viral marketing of political events in Sri Lanka. The relationship between attitude and intention has been substantiated through a wide array of previous studies on technology adoption and knowledge sharing (Yang, Liu \& Zhou 2012, Gangadharbatla 2008, Han, Hsu \& Sheu 2010, Hsu \& Lin 2008, Mishra, Akman \& Mishra 2014, Taylor \& Todd 1995, Pavlou \& Fygenson 2006, Bock, Zmud, Kim \& Lee 2005, Ranasinghe \& Dharmadasa 2013). The path coefficient $(\beta)$ of 0.19 established in the study is relatively similar to that of studies conducted by Yang (2013) and Yang, Liu \& Zhou (2012). However, the established path coefficient is smaller compared to that shown by Hsu \& Lin (2008), Pavlou \& Fygenson (2006) and Lee, Ham \& Kim (2013). The difference in the degree of relationship could be due to differences in the contexts of the research. The majority of prior studies on viral marketing intentions were conducted either in Western countries or in south east Asian countries.

The findings of the study are in line with the original TPB model which postulates that the individual's intention to engage in a particular behaviour depends on the attitude towards such behaviour, subjective norms and perceived behavioural control (Ajzen 1991, Ajzen \& Madden 1986, Ajzen 2002). Another interesting finding is that percieved behavioural control, which is a major determinant that differentiates TPB from TRA, is recognized as the most vital factor affecting one's intention to engage in viral marketing in a given context. Thus, the research is in line with the same conclusion reached by Taylor \& Todd (1995) and 


\section{NSBM Journal of Management}

Vol. 2, No. 1, January - June, 2016

determines TPB as a viable model that provides a broader explanation of technolgy adoption and engagement in viral marketing.

Among the four interpersonal communication motives which affect intention to engage in viral marketing based on Schutz (1966), only two, the need for affection and the need for control, were proved to have a significant impact on intention to engage in viral marketing in the given context. The findings substantiate that the individual's need for affection positively affects his/her intention to engage in viral marketing of political events through SNS. This finding is in line with the previous studies conducted in relation to interpersonal communication motives and eWoM (Henning-Thurau, Gwinner, Walsh \& Gremler 2004, Ho \& Dempsey 2010, Phelps, Lewis, Mobilio, Perry \& Raman 2004, Price, Feick \& Guskey 1995, Huang, Lin \& Lin 2008, Cheung \& Lee 2012). In the present study, the path coefficient $(\beta)$ was established as 0.132 , which is much in line with the findings of the aforementioned study conducted by Henning-Thurau, Gwinner, Walsh \& Gremler (2004), which identified concern for other consumers as a key determinant in engaging in viral marketing. Considering the participants of the study, the signficance of affiliation orientation can be related to Sri Lankan culture as well.

The study found support for the hypothesized relationship between need for control and intention to engage in viral marketing of political events with a positive and significant path coefficient. This was also confirmed in the study done by Sundaram, Mitra and Webster (1998) as achievement obtained by using a product and by being an intelligent shopper motivates them to share information with each other with the need to change and influence the behaviour of others in the network. Further Sun, Youn, Wu \& Kuntaraporn (2006) found that online opinion leadership with a desire to control others is positively related to online forwarding in the context of music-related communication. In addition, the study established a path coefficient of 0.23 , which is somewhat similar to the relationship established in the study of Sun, Youn, Wu \& Kuntaraporn (2006).

The significant relationship between need for control and intention to engage in viral marketing may be due to the target group of the research. Asch, as cited in Smith (2011), attributes millennial to the need to control their environment. Meanwhile, the Internet had a part in fostering this sense of control (Smith 2011). Since the communication taking place through the Internet allows millennial to exert control over the free market by expressing their opinions through a multitude of websites that potentially influence consumers, such communication may be preferred by them. Especially when it comes to political events, it is possible that individuals will post things which are aligned with their political viewpoints 
with the objective of changing or influencing others' voting behaviours. Thus it can be concluded that the need for control positively impacts on the individual's intention to engage in viral marketing of political events in Sri Lanka.

Even though the extant literature has established a positive relationship between need to belong and intention to engage in viral marketing (Leary, Kelly, Cottrell \& Schreindorfer 2013, Cheung \& Lee 2012, Phelps, Lewis, Mobilio, Perry \& Raman 2004, Metzger \& Flanagin 2013), the findings in the Sri Lankan context did not support such a relationship. There are other similar researches that did not establish such a relationship (Ho \& Dempsey 2010, Sun, Youn, Wu \& Kuntaraporn 2006). The insignificant relationship can be attributed to the purpose served by SNS. According to studies conducted by Ross, et al (2009) and Sheldon (2008), most 'Facebook Friends' were individuals known from the offline world; in other words, the Facebook was not used as a tool to meet new people online or to belong to new groups and it was just used as a tool to maintain contact with the groups to which they already belong.

Further, based on substantial amounts of literature, researchers have hypothesized a relationship between one's need for individuation and intention to engage in viral marketing (Sundaram, Mitra \& Webster 1998, Ho \& Dempsey 2010, Daugherty, Eastin \& Bright 2008; Henning-Thurau, Gwinner, Walsh \& Gremler 2004). However, the present study did not establish such a relationship as hypothesized. The findings of the study are much aligned with a study conducted by Yap, Soetarto \& Sweeney (2013) and Ghane, Shokrizadeh, Omidvar \& Kamyab (2014). It is not suggested that viral marketing is used as a means of showcasing one's uniqueness because the results of this study may have been influenced by the special personality traits of Sri Lankans. As Lee (1994) says, by nature Asians have compliant and obedient personalities and thus may not be willing to stand out from the crowd.

\section{Conclusion}

This study addressed a gap in the extant literature on viral marketing by determining factors affecting towards individuals intention to engage in viral marketing through SNS. Researcher examined motives which drives an individual to engage in viral marketing of political events through SNS in light of well established theories TPB (Ajzen 1991) and FIRO (Schutz 1966). The findings of the study have implications for both marketing practice and theory, and it enlighten about possible further research that can be undertaken on intention to engage in viral marketing. 
NSBM Journal of Management

Vol. 2, No. 1, January - June, 2016

\section{Theoretical and Practical Implications}

This study sheds light on several theoretical as well as managerial implications. The study makes a major theoretical contribution by examining factors affecting individual's intention to engage in viral marketing via SNS in light of the behavioural theory as well as the interpersonal relations theory. Further, many researchers have explored viral marketing in the Western or South East Asian context (Chan and Ngai 2011), which would not fit in with the Sri Lankan context. Thus, the study makes a contribution by examining factors affecting intention to engage in viral marketing in the Sri Lankan context. Actually, there are no corresponding studies done in Sri Lankan or South Asian contexts. The discussion and findings highlight the possible impact of some unique cultural and psychological behaviours among Sri Lankans which may be different from those of western ideologies. Hence, the findings of this study provide an insight into the viral marketing behaviours that are distinctive Sri Lankan youth behaviours. The findings can be generalized to other South Asian countries which have similar attributes in terms of culture and economic development.

Since viral marketing can be highly beneficial to a company, marketers should determine what drives consumers to write and pass along reviews about products on SNS. Hence, the findings of this study generate some useful insights for business organizations which are looking forward to embracing viral marketing in their marketing campaigns. According to the findings, viral marketing campaigns have a greater chance of success if the marketer is able to develop marketing communication strategies that appeal to the key interpersonal communication motives -need for affection and need for control. For example, in order to satisfy the need for affection among young individuals, online opinion platform moderators should provide a mechanism whereby members who have provided useful suggestions to other members are recognized and informed that they have helped others. Further, if a particular platform operator can link senders and readers via person-to-person messaging, it will enable readers to show their appreciation for the reviews received. This may satisfy the contributors' need for control by presuming that they were able to influence the decisions of others.

Further, the findings substantiated that individuals tend to engage in writing and spreading messages when they feel that their friends and relatives accept and engage in viral marketing on SNS. Platform operators can work on sending personalized updates to individuals about those friends who engage in diffusing messages. Also, posting a public note of appreciation to contributors for spreading the message will enable the individuals in his friends' list to know that he engages in viral marketing. This may give a boost to individuals to get involved in diffusing messages as a norm among their friends. 
The findings also reveal the pivotal impact of perceived behavioural control on the individual's intention to engage in viral marketing. To enhance the viral nature of the message, marketers should always work on enhancing the customers' level of confidence in the ease of performing the task with few obstacles and resource constraints. For example, most young Sri Lankans find it difficult to diffuse highly sophisticated rich content due to Internet bandwidth issues in the country. Thus, they may avoid diffusing messages of such calibre which may freeze the buzz. In order for practitioners to foster eWOM engagement activities on SNS, user-friendliness needs to be considered when providing service features such as searching, listening, and viewing, purchasing and sharing. Perceived behavioural control can be enhanced by platform operators through usability evaluation, service process reengineering, or user-centered design. Digital marketing practitioners can improve the system by designing a more controllable user interface, eliminating unnecessary plug-ins, enabling easier communication among peers and organizing the information architecture to enable users to more easily navigate its services in their fan pages and applications.

\section{Limitations and Further Research}

While this study's findings have considerable potential implications, there are several limitations. Firstly, the researcher has drawn her sample from undergraduates as they are considered appropriate participants because of their tech savvy and substantial use of SNS. However, to get a broader picture of viral marketing behaviour among young individuals future research needs to pay attention to wider groups from diverse settings. This will enhance the generalizability of findings which is a foremost objective of conducting a quantitative study.

Secondly, the study relates to the context of viral marketing of political events in Sri Lanka. The use of viral marketing for political events is considered viable since many of the Sri Lankan brands are still not able to reach maximum benefits by utilizing eWoM through SNS (Thajudeen 2012) and the exception for this is an unprecedented use of social media in political campaigns (Gunawardena 2015). However, in general people do not have much of a good perception about politics in Sri Lanka and it may have impacted the responses. Thus, it is necessary to project the derived model to other settings such as viral marketing of fast moving consumer goods, fashion, etc. in order to get a broader view.

Thirdly, though the study was limited to the determinants of intention derived from FIRO theory and TPB model, there are many interpersonal psychological and behavioural theories that can be used to explain the determinants of eWOM intention. Examples of such theories 


\section{NSBM Journal of Management}

Vol. 2, No. 1, January - June, 2016

are social exchange theory, equity theory, balance theory and theory of reasoned action (Chan and Ngai 2011). Hence, further research can be enriched by using more motivational and behavioural theories and exploring interactive behaviour, which has not been sufficiently explored (Liu 2007). Further, the need for belongingness and individuation might not have a direct impact on intention to engage in eWOM. Instead, it might have an indirect effect through mediation, which can be tested in future research. Finally, it is also possible that consumers' pass-along intentions may also depend on the type of content of the message (Lee, Ham, \& Kim 2013) where people perceive some messages more viral than others. Therefore, future research needs to test how eWOM motives impact through different types of online messages.

\section{References}

Abbas, S \& Singh, CAK 2014, Social Media MODI-FICATION: Narendra Modi's use of Social Media in Indian Elections 2014, Osaka, Japan

Ajzen, I 1991, 'The theory of planned behaviour', Organiztaional Behaviour and Human Decision Process, vol. 50, pp. 179-211.

Ajzen, I 2002, 'Perceived behavioral control, self-efficacy, locus of control, and the theory of planned behavior', Journal of Applied Social Psychology, vol. 32, no.4 , pp. 665-683.

Ajzen, I \& Madden, T 1986, 'Prediction of Goal Directed Behavior: Attitudes, Intentions \& Perceived Behavioral Control', Journal of Experimental Social Psychology, vol. 22, pp. 453-474.

Anderson, JC \& Gerbing, DW 1988, 'Structural equation modeling in practice: a review and recommended two-step approach', Psychological Bulletin, vol. 103, no. 3, pp. 411-423.

Askew, K, Buckner, JE, Taing, MU, Ilie, Alex, Bauer, JA, Coovert, MD, 2014, 'Explaining cyberloafing: the role of the theory of planned behavior', Computers in Human Behavior, vol. 36, pp. 510-519.

Bagozzi, RP \& Yi, Y 1988, 'On the evaluation of structural equation models”, Journal of the Academy of Marketing Science, vol. 16, no. 01, pp. 74-94.

Bickart, B \& Schindler, R 2001, 'Internet forums as influential sources of consumer information', Journal of Interactive Marketing, vol. 15, pp. 31-40.

Bock, GW, Zmud, RW, Kim , YG \& Lee, JN 2005, 'Behavioral intention formation in knowledge sharing: examining the roles of extrinsic motivators, social-psychological forces, and organizational climate', MIS Quarterly, March, vol. 29, no. 1, pp. 87-111.

Camarero, C \& San Jose, R 2011, 'Social \& attitudinal dynamics of viral marketing dynamics', Computers in Human Behaviour, vol. 27, no. 6, pp. 2292-2300.

Chaney, IM 2001, 'Opinion leaders as a segment for marketing communications', Marketing Intelligence \& Planning, vol. 19 , no. 5 , pp. 302-308.

Chan, YYY \& Ngai, EWT 2011, 'Conceptualising electronic word of mouth activity: an inout process output perspective', Marketing Intelligence \& Planning, vol. 29, no. 5, pp. 488-519. 
Cheung, CMK \& Lee, MKO 2012, 'What drives consumers to spread electronic word of mouth in online consumer-opinion platforms', Decision Support Systems, vol. 53, no. 1, pp. 218-225.

Cheung, CMK \& Thadani, DR 2012, 'The impact of electronic word-of-mouth commuincation: a literature analysis \& integrative model', Decision Support Systems, vol. 54, no. 01, pp. 461-470.

Cheung, R \& Vogel, D 2013, 'Predicting user acceptance of collaborative technologies: an extension of the technology acceptance model for e-learning', Computers \& Education, vol. 63, pp. 160-175.

Chung, CMY \& Darke, PR 2006, 'The consumer as advocate: self-relevance, culture, and word-ofmouth', Market Lett, vol. 17, pp. 269-279.

Daugherty, T, Eastin, MS \& Bright, L 2008, 'Exploring consumer motivations for creating usergenerated content', Journal of Interactive Advertising, vol. 8, no. 2, pp. 16-25.

eMarketer, Inc. (2013, February). Online User Reviews: Building Trust and Boosting Sales. Retrieved from www.s3.amazonaws.com: https://s3.amazonaws.com/readypulse/news/eMarketer-online-userreviews-building-trust_and_boosting-sales.pdf

Gangadharbatla , H 2008, 'Facebook me: collectve self-esteem, need to belong, and internet self efficacy as predictors of the i-genration's attitudes towards social networking sites', Journal of Interactive Advertising, vol. 8, no. 2, pp. 5-15.

Ghane, N, Shokrizadeh, HR, Omidvar, M \& Kamyab, H 2014, 'Investigating the effective factors on electronic trade by viral marketing (case study: clients of websites in iran)', European Journal of Business and Management, vol. 06, no. 34, pp. 173-180.

Grunert, K G \& Ramus , K 2005, 'Consumers' willingness to buy food through the internet: a review of the literature and a model for future research', British Food Journal, vol.107, no. 6, pp. 381-403.

Gunawardena, N 2015, 'Emerging digital democracy? Social media and Sri Lanka's presidention election 2015', Institue of Common Wealth Studies \& Common Wealth Journalists' Association, London.

Hair, J, Black, WC, Babin, BJ \& Anderson, RE 2009, Multivariate Data Analysis, 7 th edn., Prentice Hall, London.

Han, H, Hsu, L T \& Sheu, C 2010, 'Application of the theory of planned behavior to green hotel choice: testing the effect of environmental friendly activities', Tourism Management, vol. 31, no. 3, pp. 325334.

Henning-Thurau, T, Gwinner, KP, Walsh, G \& Gremler, DD 2004, 'Electronic word-of-mouth via consumer-opinion platforms: what motivates consumers to articulate themselves on the Internet?', Journal of Interactive Marketing, vol. 12, pp. 40-52.

Ho, YCJ \& Dempsey, M 2010, 'Viral marketing: motivations to forward online content', Journal of Business Research, vol. 63, pp. 1000-1006.

Hooper, D., Couglan, J., \& Mullen, M. R. (2008). Structural Equation Modelling: Guidelines for Determining Model Fit. Electronic Journal of Business Research Methods, 06(01), 53-60

Hsu, C L \& Lin, C C 2008 "Acceptance of blog usage: the roles of technology acceptance, social influence \& knowledge sharing motivation”, Information \& Management, vol.45, pp. 65-74. 


\section{NSBM Journal of Management}

Vol. 2, No. 1, January - June, 2016

Huang, CC, Lin, TC \& Lin, KJ 2008, 'Factors affecting pass-along email intentions (PAEIs): integrating the social capital \& social cognition theories', Electronic Commerce Research and Applications, November, vol. 8, no. 3, pp. 160-169.

José-Cabezudo, RS \& Camarero-Izquierdo, C 2013, 'Determinants of opening-forwarding e-mail messages', Journal of Advertising, vol. 41, no. 2, March, pp. 97-112.

Kaplan, AM \& Haenlein, M 2011, 'Two hearts in three-qurter time: How to waltz the social media/viral marketing dance', Business Horizons, vol. 54, no. 3, May-June, pp. 253-263.

Leary, MR, Kelly, KM, Cottrell, CA \& Schreindorfer, LS 2013, 'Construct validity of the need to belong scale: mapping the nomological network', Journal of Personality Assessment, vol. 95, no. 6, pp. 610-624.

Lee, S 1994,'Behind the model-minority stereotype: voices of high- and low-achieving Asian American students', Anthropology \& Education Quarterly, vol. 25, no. 04, pp. 413-429.

Lee, J, Ham, CD \& Kim, M 2013, 'Why people pass along online video advertising: from the perspectives of the interpersonal communication motives scale and the theory of reasoned action', Journal of Interactive Advertising, vol. 13, no. 1, pp. 01-13.

Lin, H F \& Lee, G G 2004, 'Perceptions of senior managers toward knowledge-sharing behaviour', Management Decision, vol. 42, no. 01, pp. 108-125.

Malhotra, N K \& Dash, S 2011, Marketing Research: An Applied Orientation, $6^{\text {th }}$ edn., Dorling Kindersley (India) Pvt. Ltd., India:

Maslach , C, Stapp, J \& Santee, R T 1985, 'Individuation: conceptual analysis and assessment', Journal of Personality and Social Psychology, vol. 49 , no. 3, pp. 729-738.

Metzger, MJ \& Flanagin, AJ 2013, 'Credibility and trust of information in online environments:the use of cognitive heuristics', Journal of Pragmatics, vol. 59, pp. 210-229.

Mishra, D, Akman, I \& Mishra, A 2014. 'Theory of reasoned action application for green information technology acceptance', Computers in Human Behavior, vol. 36, pp. 29-40.

Palka, W, Pousttchi, K \& Wiedemann, DG 2009, 'Mobile word-of-mouth - a grounded theory of mobile viral marketing', Journal of Information Technology, vol.24, pp. 172-185.

Pavlou , PA \& Fygenson, M 2006, 'Understanding \& predicting electronic commerce adoption: an extention of the theory of planned behvior', MIS Quarterly, vol.30, no. 1, pp. 115-143.

Phelps, JE, Lewis, R, Mobilio, LZ, Perry, D, \& Raman, N, 2004, 'Viral marketing or electronic wordof-mouth advertising: examining consumer responses and motivations to pass along email', Journal of Advertising Research, December, vol. 44, no. 4, pp. 333-348.

Price, L L, Feick, L F \& Guskey, A 1995, 'Everyday market helping behavior', Journal of Public Policy \& Marketing, vol. 14, no. 2, pp. 255-266.

Ranasinghe, SB \& Dharmadasa, P 2013, 'Intention to knowledge sharing: from planned behavior and psychological needs perspective', International Journal of Knowledge Management, vol. 9, no. 4, pp. 33-50. 
Ross, C, Orr, ES, Sisic, M, Arseneault, JM, Simmering, MG \& Orr, RR, 2009, 'Personality and motivations associated with Facebook use', Computers in Human Behavior, vol. 25, pp. 578-586.

Rubin, RR, Perse, EM \& Barbato, CA 1988, 'Conceptualization and measurement of interpersonal communication motives', Human Communication Research, vol. 14, no. 4, pp. 602-628.

Saunders, M, Lewis, P \& Thornhill, A 2011, Research Methods for Business Students, Dorling Kindersley India Pvt. Ltd.

Schutz, WC 1966, The Interpersonal Underworld, Science \& Behvaior Books, Inc., California.

Sekaran, U \& Bougie, R 2014, Research Methods for Business A Skill Building Approach, $5^{\text {th }}$ edn., Wiley India (P.) Ltd.

Sheldon, P 2008, 'The relationship between unwillingness-to-communicate and students' facebook use', Journal of Media Psychology, vol. 20, no. 2, pp. 67-75.

Smith, KT 2011, 'Digital marketing strategies that Millennials find appealing, motivating, or just annoying', Journal of Strategic Marketing, vol. 19, no. 6, pp. 489-499.

Smith, KT 2012, 'Longitudinal study of digital marketing strategies targeting Millennials', Journal of Consumer Marketing, vol. 29, no. 2, pp. 86-92.

Sundaram, MS, Mitra, K \& Webster , C 1998, 'Word-of-mouth communications: a motivational analysis', Advances in Consumer Research, vol. 25, pp. 527-531.

Sun, T, Youn, S, Wu, G \& Kuntaraporn, M 2006, 'Online word-of-mouth (or mouse):an exploration of its antecedentsand consequences', Journal of Computer-Mediated Communication, vol. 11, pp. 11041027.

Taylor, S \& Todd, PA 1995, 'Understanding information technology usage: a test of competing models, Information Systems Research, vol.6, no. 2, pp. 144-176.

Thajudeen, T 2012, Insights into Social Media on Brand Finance Top 100 Brands in Sri Lanka. [Online] Available at: http://www.ft.lk/2012/10/12/insights-into-social-media-on-brand-finance-top100-brands-in-sri-lanka/ [Accessed 5 May 2015].

UNESCO, 2014. What do we mean by 'youth'? [Online] Available at: http://www.unesco.org/new/en/ social-and-human-sciences/themes/youth/youth-definition/[Accessed 10 May 2015].

Vilpponen, A, Winter, S \& Sundqvist, S 2006, 'Electronic word-of-mouth in online environments: exploring referral network structure and adoption behavior', Journal of Interactive Advertising, vol. 6, no. 2, pp. 63-77.

Yang, H 2013, 'Market mavens in social media: examining young chinese consumers' viral marketing attitude, ewom motive, and behavior', Journal of Asia-Pacific Business, vol. 14, no. 2, pp. 154-178.

Yang, H, Liu, H \& Zhou, L 2012, 'Predicting young Chinese consumers' mobile viral attitudes, intents \& behavior', Asia Pacific Journal of Marketing \& Logistics, vol. 24, no. 1, pp. 59-77.

Yap, KB, Soetarto, B \& Sweeney, JC 2013, 'The relationship between electronic word-of-mouth motivations and message characteristics: the sender's perspective', Australasian Marketing Journal, vol. 21, pp. 66-74. 
NSBM Journal of Management

Vol. 2, No. 1, January - June, 2016

\section{Appendix 1}

Measures

Attitude (ATT) Yang, Liu, \& Zhou (2012)

ATT 01 My attitude toward passing along electronic messages about political events is positive

ATT 02 Generally,I think it is good to pass along electronic messages about political events to friends or relatives

ATT 03 I honestly don't like passing along electronic messages about political events to friends or relatives (R)

\begin{tabular}{lll}
\hline Subjective Norms & Han, Hsu, \& Sheu & SN 01 Most people who are important to me think I should \\
(SN) & $(2010)$ & pass along posts about political events
\end{tabular}

SN 02 Most people who are important to me would want me to pass along posts about political events

SN 03 People whose opinions I value would prefer to see that I pass along messages about political events.

\begin{tabular}{|c|c|c|}
\hline \multirow[t]{3}{*}{ PBC } & Taylor \& Todd (1995) & $\begin{array}{l}\text { PBC } 01 \text { I would be able to passing along electronic messages } \\
\text { about political events }\end{array}$ \\
\hline & & $\begin{array}{l}\text { PBC } 02 \text { Passing along electronic messages about political } \\
\text { events to my friends \& relatives are entirely within my control }\end{array}$ \\
\hline & & $\begin{array}{l}\text { PBC } 03 \text { I have the resources and the knowledge and the } \\
\text { ability to pass along electronic messages about political events }\end{array}$ \\
\hline $\begin{array}{l}\text { Need to belong } \\
\text { (NTB) }\end{array}$ & $\begin{array}{l}\text { Leary, Kelly, Cottrell, } \\
\text { \&Schreindorfer (2013) }\end{array}$ & $\begin{array}{l}\text { NTB } 01 \text { If other people don't seem to accept me, I don't let it } \\
\text { bother me. (R) }\end{array}$ \\
\hline
\end{tabular}

NTB 02 I try hard not to do things that will make other people avoid or reject me.

NTB 03 I seldom worry about whether other people care about me. (R)

NTB 04 I need to feel that there are people I can turn to in times of need.

NTB 05 I want other people to accept me.

NTB 06 I do not like being alone.

NTB 07 Being apart from my friends for long periods of time does not bother me. (R)

NTB 08 I have a strong "need to belong."

NTB 09 It bothers me a great deal when I am not included in other people's plans.

NTB 10 My feelings are easily hurt when I feel that others do not accept me.

\begin{tabular}{ll}
\hline Need to & Maslach, Stapp, \& \\
Individuation (NTI) & Santee (1985)
\end{tabular}

NTI 01 Give a lecture to a large audience.

NTI 02 Raise your hand to ask a question in meeting or lecture.

NTI 03 Volunteer to head a committee for a group of people you do not know very well.

NTI 04 Tell a person that you like him/her. 
NTI 05 Publicly challenge a speaker whose position clashes with your own.

NTI 06 Accept a nomination to be a leader of a group.

NTI 07 Present a personal opinion, on a controversial issue, to a group of strangers.

NTI 08 When asked to introduce yourself, say something more personal about yourself than just your name and occupation.

NTI 09 Give an informal talk in front of a small group of classmates or colleagues.

NTI 10 Speak up about your ideas even though you are uncertain of whether you are correct.

NTI 11 Perform on a stage before a large audience.

NTI 12 Give your opinion on a controversial issue, even though no one has asked for it.

\begin{tabular}{ll}
\hline Need for Affection & Rubin, Perse , \& \\
(NFA) & Barbato (1988)
\end{tabular}

NFA 01 I will pass along electronic messages about political events to help others

NFA 02 I will pass along electronic messages about political events let others know I care about their feelings

NFA 03 I will pass along electronic messages about political events to thank people

NFA 04 I will pass along electronic messages about political events to show others encouragement

NFA 05 I will pass along electronic messages about political events because I'm concern about others

\begin{tabular}{|c|c|c|}
\hline \multirow[t]{3}{*}{$\begin{array}{l}\text { Need for Control } \\
\text { (NFC) }\end{array}$} & $\begin{array}{l}\text { Rubin, Perse , \& } \\
\text { Barbato (1988) }\end{array}$ & $\begin{array}{l}\text { NFC } 01 \text { Passing along electronic messages about political } \\
\text { events will help me to have someone to do something for me }\end{array}$ \\
\hline & & $\begin{array}{l}\text { NFC } 02 \text { Passing along electronic messages about political } \\
\text { events will help me to tell others what to do }\end{array}$ \\
\hline & & $\begin{array}{l}\text { NFC } 03 \text { Passing along electronic messages about political } \\
\text { events will help me to get something I don't have }\end{array}$ \\
\hline \multirow[t]{3}{*}{ Intention (INT) } & $\begin{array}{l}\text { Bock, Zmud , Kim , \& } \\
\text { Lee (2005) }\end{array}$ & $\begin{array}{l}\text { INT } 01 \text { I intend to share electronic messages about political } \\
\text { events with others more frequently in future }\end{array}$ \\
\hline & & $\begin{array}{l}\text { INT } 02 \text { I will always provide my views about political events } \\
\text { at the request of other members in SNS }\end{array}$ \\
\hline & & $\begin{array}{l}\text { INT } 03 \text { I will try to share posts about political events with } \\
\text { other members in SNS in a more effective way }\end{array}$ \\
\hline
\end{tabular}

